\title{
Juridical Review Of Legal Protection For Domestic Workers (PRT)
}

\section{Mario Borneo Tarigan}

Sumatera University Faculty Of Law. E-mail: marioborneo21@gmail.com

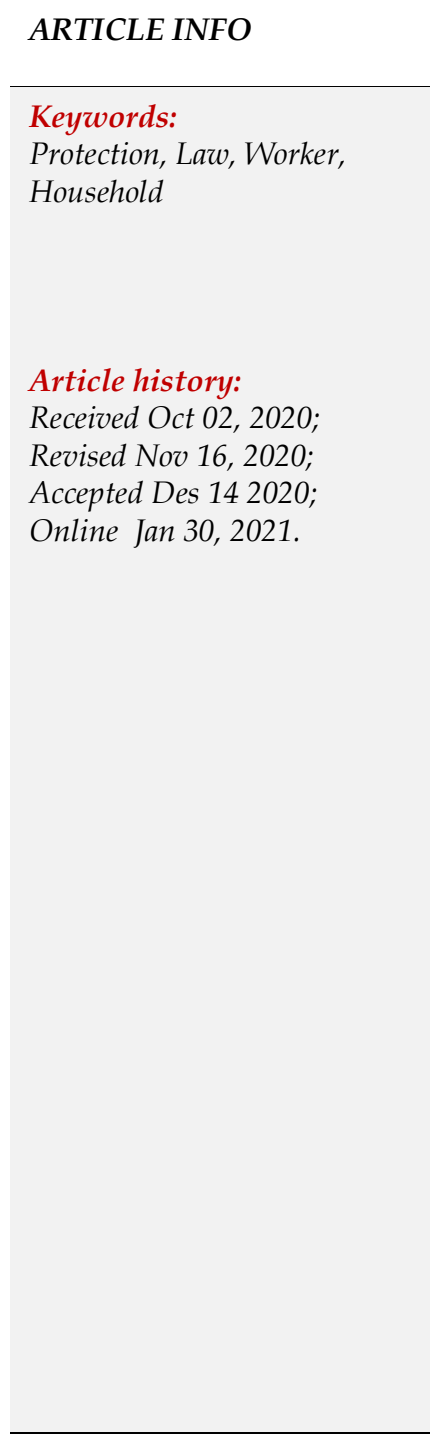

\begin{abstract}
The existence of domestic workers or better known as domestic helpers is no stranger to the lives of Indonesian people, both in cities and in villages. The formulation of the problem in this study is: What is the Legal Position of Domestic Workers (PRT) in the Work Law in Indonesia? How are cases of domestic workers (PRT) resolved? What is the need for special arrangements for domestic workers (PRT) in the law. The method used is a normative research method which is a scientific research procedure to find the truth based on legal scientific logic from the normative side Legal Position of Domestic Workers (Prt) in Indonesian Work Law. Domestic workers are definitively recognized for their legal position as workers as referred to in Law Number 13 of 2003 concerning Manpower. According to Article 86 paragraph 1 of Law Number 13 of 2003 concerning manpower, it is stated that: "Every worker/labor has the right to obtain protection for (a) occupational safety and health, (b) morals and decency; and (c) treatment in accordance with human dignity and religious values. The consensus deliberation process is carried out between domestic workers and their employers and/or domestic service providers as the simplest step to resolve disputes. Deliberations were taken for the first time without the involvement of local government officials. However, if necessary, local government officials can serve as witnesses in the deliberations. In making decisions through deliberation to reach consensus, time is limited so that it does not drag on and a sense of justice is fulfilled in an effort to provide legal certainty for the parties The need for special arrangements for home workersDomestic workers (PRT) are an important source of livelihood for women and men in Southeast Asia. Because the work is done within the household and is considered informal work, there are no regulations governing it, and as a result it often goes unnoticed. This is a category of work that is in dire need of legal and social protection, as its workers are vulnerable to harassment and exploitation during recruitment and placement, during work, and upon return to their place of origin. This paper summarizes the main problems faced by domestic workers, as well as the obstacles experienced in obtaining their rights.
\end{abstract}

This is an open access article under the CC BY-NC license.

\section{Introduction}

The existence of domestic workers or better known as domestic helpers is no stranger to the lives of Indonesian people, both in cities and in villages. Many families have domestic workers (PRT). According to the 1999 BPS SUSENAS in Jakarta, there are 168,319 domestic workers. 
This number includes both adult domestic workers and children (child domestic workers) aged between 10-18 years. The number of domestic workers is $29.9 \%$ of all domestic workers in Jakarta. Domestic workers carry out household tasks such as washing, cooking, cleaning the house, taking care of the employer's children and various other tasks assigned by the employer. In other words, the work that domestic workers have to do is numerous and varied depending on the employer's household life.

In return for their work, domestic workers receive wages from their employers. The amount of wages depends on the agreement between the domestic worker and the employer which is often based on the market price in a certain area. In some cases, wages are also based on the employer's financial condition. ${ }^{4}$ In addition to wages, domestic workers also receive various other facilities such as room, soap, toothbrush and toothpaste, and other forms of facilities provided by the employer based on their agreement.

Seeing the above phenomenon, the question arises whether domestic workers are workers who deserve the same position as other workers. The designation and acceptance of domestic workers as workers will certainly give domestic workers a new status as formal workers. The new status allows domestic workers to fight for their rights more openly. ${ }^{6}$ Experience in several neighboring countries shows this. Malaysia, Thailand and Singapore already have a statutory provision that recognizes the existence of domestic workers and provides proper legal protection, although limited to domestic workers of their own nationality.

It must be admitted that until now the existence of domestic workers as workers is not accepted by all parties. Domestic workers are not recognized as the same workforce as other workers such as factory workers, companies, etc. It must even be admitted that nowadays the term "worker" has not been accepted by society. In general, people are more receptive to referring to domestic workers as "helpers". Therefore, domestic workers are included in the scope of work in the informal sector.

The mention of domestic workers as workers has actually been included in the definition of workers or workers contained in the laws and regulations. The latest law on manpower (Law No. 13 of 2003) defines a worker/laborer as anyone who works for wages or other forms of remuneration. (Article 1 point 3). Based on this understanding, it appears that domestic workers should be included in the formal sector workers who are protected by the provisions of the law. However, the view of domestic workers as non-formal workers has been embedded in the public's view. ${ }^{9}$ In addition, the absence of direct mention of the term domestic workers as workers in the provisions of the law has strengthened the public's view and furthermore, in practice domestic workers are still not included in the scope of labor law.

This weakness or lack of juridical references has the impact that domestic workers do not get legal protection. As seen above, the recognition of domestic workers as workers on the same level as the formal sector is still lacking. Recognition of the existence of domestic workers as workers is the first step to gain social and legal recognition. ${ }^{10}$ The existence of social and legal recognition will certainly make it easier to make laws and regulations that directly provide protection to domestic workers. Thus, the juridical reference becomes clear for domestic workers and domestic workers and the community.

The existence of laws and regulations is very important to provide legal certainty for domestic workers in obtaining their rights and carrying out their obligations. Of course, this also applies to service users who employ domestic workers. Both parties can avoid abuse of power in the working relationship between domestic workers and their service users. 


\section{Method}

The method used is a normative research method which is a scientific research procedure to find the truth based on the logic of legal scholarship from the normative side. ${ }^{16}$ Scientific logic which is also in normative legal research is built based on scientific disciplines and the workings of normative legal science, namely legal science whose object is law itself.

Thus this research includes research on legal sources, legislation, court decisions, related documents and several books on legal protection of Indonesian workers. Secondary data that has been systematically compiled and then analyzed using deductive and inductive methods. The deductive method is carried out by reading, interpreting and comparing, while the inductive method is carried out by translating various sources related to the topic of this thesis, so that conclusions are obtained that are in accordance with the research objectives that have been formulated.

\section{Analysis And Results}

\subsection{Settlement Mechanism For Cases Experienced By Domestic Workers}

\section{a. Domestic Helper Legal Issues}

PRT was originally an abbreviation of Domestic Helper, has now been shifted to Domestic Worker. This term wants to strengthen and give recognition to people who work in a household. This term appears to replace the term maid, servant, maid, or babu.

This one problem, it must be admitted that it still receives less attention, both in the context of domestic workers who become TKW/migrants, child domestic workers, as well as domestic domestic workers issues. In urban areas in Indonesia there is a high demand for domestic workers (PRT). The presence and high demand for domestic workers has raised human rights issues. First, the number of domestic workers is quite large so that the potential for violations of their rights as workers is also large. This happens because until now there are no clear regulations governing the employment relationship and legal protection for these domestic workers. According to a survey by the International Labor Organization, ILO-IPEC, which was conducted in 2003 in Bekasi and East Jakarta, the results were then calculated to obtain the number of domestic workers in Indonesia, 2,593,399 people, and the number of child domestic workers (PART) is 688,132 children. Second, the reality on the ground shows that domestic workers are very vulnerable to unfair treatment such as uncertainty in terms of wages, inhumane treatment, and erratic working hours. Third, that the majority of domestic workers are women and many of them have also received violent treatment, both physical violence and sexual violence, such as sexual harassment to rape.

Cases of violence against domestic workers are often reported in the mass media. In many cases, domestic workers are not able to escape the torture of their employers because they do not have money and they do not know the environment in which they live. Because until now there are no legal provisions governing the admission process, work environment standards, workload and working conditions for domestic workers, domestic workers are vulnerable to violence.

The PRT problem is indeed quite complicated. This problem is even more complicated because there is no legal instrument that regulates it. This problem does not stop at labor supply agencies that do not follow official regulations, but extends to the economic, social, cultural, and legal systems. Therefore, the problem of domestic workers is a structural problem and working conditions that are closely related to poverty and impoverishment. 
The work of domestic workers is closely related to the phenomenon of feminization of poverty. This work is usually done by poor women, especially from rural areas and is paid low wages. This job also does not have a career path and is not protected by law. Therefore, the situation faced by domestic workers is structural, namely related to social, economic, cultural and legal issues. To overcome these structural problems, fundamental changes are needed, especially in the social and economic fields at the national level.

There are two main structural problems faced by domestic workers:

1) Poverty.

The poverty experienced by domestic workers families has caused them to lose the opportunity to go to school, which also causes them to be unable to acquire the skills needed to enter the labor market and find decent work. As a result, they are trapped into unsanitary working conditions, which can become forced labour. Low wages mean that they will not be able to send their children to a higher level in school, so that their children will not be far from their parents. Reducing poverty will help reduce the poor working and living conditions of domestic workers.

2) Discrimination.

The discrimination experienced by female domestic workers is based on the construction of gender and social class. As poor women who offer services that are considered not to require special skills, causing domestic workers to have no bargaining power when dealing with their employers. The construction of gender and social class also makes them passive and takes things for granted, and the construction of gender also makes them pay less than other housework, such as driving. Organizing domestic workers so that they can.

\section{b. Family Settlement Through Mediation by Police or Non-Governmental Organizations (NGOs)}

The cases of violence experienced by domestic workers in the city of Medan have not yet received serious attention from local government officials. This is because there are no clear guidelines in the laws and regulations that specifically regulate the protection of domestic workers, so that the response of the local government in this case the SKPD that handles the labor sector to complaints about domestic workers is still very low. Included here are Regional Regulations that do not yet regulate the Protection of Domestic Workers. So far, local governments have only received complaints from trafficked domestic workers.

As for cases of violence against domestic workers, it is entirely left to the police.The community has so far participated directly in the handling of domestic workers who are victims of violence by employers. This can be seen from the case experienced by a domestic worker named Yani (a speech-impaired domestic worker) who has been working since November 4, 2007, who often received harsh treatment from the employer. When the local community learns of torture by the Employer, they try to protect it by reporting it to the head of the local environment. However, there is no coordination between government officials regarding the settlement of the domestic worker case, starting from the reporting stage to the dispute resolution stage.

The process of reporting cases of domestic workers is still too convoluted. This is because there is no law that regulates the protection of domestic workers, so that the public and government officials do not clearly know the mechanism for reporting procedures or complaints related to cases of torture or violations against domestic workers. Only a few cases of domestic workers in Medan City have been settled at the court level. Until now, only the case of PRT Mariani Sambas has been decided by the court where the perpetrator (the Employer) is sentenced to probation for 1 (one) month.

Most cases are resolved amicably. This is due to the unclear mechanism for resolving cases of domestic workers, so efforts have been taken to peacefully by the police who are known by the 
community and the RT/RW management. Thus, the case stopped in the middle of the road, considering that the peaceful method did not touch the rights that domestic workers should have received. Almost all domestic workers cases handled by Sahdar's NGO failed to be brought to the PPHI mediation and judicial dispute process, because the police, who handled domestic workers' cases without looking at the context of civil disputes, resolved them through peaceful means.

Regarding data on domestic workers and the foundation for domestic workers service providers in the city of Medan, until now the NGO Sahdar does not have this data. Even local officials have never received reports of domestic workers and foundations in their area. In addition, there is no clear procedure in the kelurahan regarding data collection on the presence of domestic workers living in the employer's house. This makes it difficult for NGOs to register domestic workers who work for employers, if there is no cover letter from the local kelurahan office as desired by the employer.

So far, domestic workers are considered as informal workers, so there is no clear data collection mechanism from local officials. There is no initiative from the authorities to record the whereabouts of domestic workers working in their area. Regarding domestic workers, there are still domestic workers who are employed without the knowledge of local officials. The existence of domestic workers is only known after a problem occurs with the Employer. As for the wages of domestic workers, domestic service providers make a lot of deductions from wages that are distributed to service providers.

c. Several Cases Concerning Domestic Workers.

1) The Case of Domestic Workers (PRT) Nuryani alias Yani

a) About Victims

The victim's name is Yani, about 15 years old, united as an orphan. The victim is a domestic worker (PRT) at her employer's house on Jalan Merpati 1, Perumnas Mandala, Bantam Village, Medan Tembung District, Medan. Yani has been working for approximately 3 years. Yani is a different able who cannot communicate normally. According to information obtained from neighbors, Yani is from Jakarta.

b) About Employer

Yani's female employer named Br. Tambunan, works at a private bank in the city of Medan. The male employer is known by the name of Mr. Sagala, a lecturer at a private university in the city of Medan. Mrs. Tambunan and Mr. Sagala live on Jalan Merpati 1 Perumnas Mandala Medan. These two employers leave for work every day from the morning and usually return in the afternoon.

\section{c) Working Condition}

Yani works live at the employer's house, and does all household chores. Yani's work while working at her employer's house is cooking, scrubbing clothes, washing clothes, sweeping, mopping and keeping the house. Yani is not allowed to leave the house by the female employer, but by Sagala, Yani is not prohibited from leaving the house.

d) Chronology of Events Morning and noon

On Wednesday 27 April 2011 at around 10.00 WIB, Yani left the employer's house and headed for Ani's mother's house. Ani's mother's house is 2 (two) houses away from her employer's house to the north along Jalan Merpati 1. Yani admits that he can't stand the treatment of his employer. Ani's mother and neighbors, who knew about Yani's condition and all the treatment she had received from her employer, protected her at Ani's mother's house. 
At around 11.50 am three representatives from the Teratai KPRT and two people from SAHDAR visited Ibu Ani's residence. Inside the house, sitting in rows on the floor, Ani's mother, Yani, two other neighbors, and representatives of the Teratai and SAHDAR domestic workers. During the conversation, Ani's mother explained that Yani had left the house without her employer's knowledge. Now Yani doesn't want to go back to her employer's house for fear. After about five minutes of talking, 4 other neighbors came to testify that they often heard complaints about Yani being treated rudely by his employer, had not eaten, and did not receive a salary. The rough treatment that Yani received can be seen from the red pinch marks on Yani's cheeks on the right and left.

According to the information given in sign language, Yani demonstrated that she was often pinched, grabbed, slapped and banged her head against the wall of the house. Yani has often complained to her neighbors about her employer's harsh treatment of her. Sometimes he even tells stories with tears in his eyes because he hasn't eaten.

Until the process of seeking this information, Yani stated that he was not willing to return to the employer's house. The neighbors also did not allow Yani to return, and insisted on keeping Yani at Ani's mother's house. They (neighbors) did not allow or even wanted to protect Yani from the harsh treatment of her employer. Ani's mother is also willing if Yani stays with her at home and hires her. The other neighbors also stated that they would protect Yani and keep Yani from returning to her employer's house, and they were willing to testify to the treatment that happened to Yani.

\subsection{The Need For Special Regulations For Household Workers (Prt) In Law}

a. The need for special arrangements regarding domestic workers (PRT)

Work as domestic workers (PRT) is an important source of livelihood for women and men in developing countries such as Indonesia. Because the work is done within the household and is considered informal work, there are no regulations governing it, and as a result it often goes unnoticed. This is a category of work that is in dire need of legal and social protection, as workers are vulnerable to harassment and exploitation during recruitment and job placement, during work, and upon return to their area of origin. This paper summarizes the main problems faced by domestic workers, as well as the obstacles experienced in achieving their rights. Both men and women work as domestic workers, but women make up the majority and are most affected by abuse and exploitation.

\section{b. DPR's Version of the Domestic Worker Bill}

Various elements of society in Indonesia, including from the government, have jointly drafted the Bill on the Protection of Domestic Workers, but there is still a long way to go to ratify it as a law in Commission IX of the DPR. With the Law on the Protection of Domestic Workers (PRT), domestic workers are recognized as workers who get legal protection, this legal protection is not only seen and made from legality alone but the most important thing is the perspective and sensitivity of the protection itself which is based on respect, enforcement, and respect for human beings with their inherent and non-discriminatory rights to gender, nation, race, religion, ethnicity, language, skin color.

1) Philosophical reasons for the need for a law on domestic workers

The Preamble to the 1945 Constitution of the Republic of Indonesia (UUD NRI 1945) mandates that one of the goals of the state is is to protect the entire Indonesian nation and the entire homeland of Indonesia. Therefore, the state is obliged to protect every citizen from all forms of inhumane treatment, such as harassment, violence, and discrimination which ultimately result in human rights violations. The state is committed to realizing the ideals of humanity by providing protection to every citizen in the form of ensuring security, comfort and welfare. Security in question is the existence of safety and tranquility of life for every Indonesian citizen 
(WNI) both inside and outside the territory of Indonesia, and every foreign citizen (WNA) residing in the territory of Indonesia. In addition, providing a comfortable life becomes an inseparable part of the purpose of the state. Therefore, Every citizen has the right to get and feel comfort in various forms. The availability of basic rights as citizens is a prerequisite for creating a sense of comfort. The mandate of the 1945 Constitution of the Republic of Indonesia was reaffirmed through the 2nd and 5th precepts of Pancasila. The second principle, "Just and civilized humanity," is an acknowledgment of human values that must be upheld and elaborated through a series of policies that favor all people. In this context, every person/citizen is treated equally and with dignity, regardless of social, economic, or political position. The fifth principle, "Social justice for all Indonesian people" provides clear and firm direction to the state that the people must be treated fairly in the fulfillment of their economicsocial rights. As a citizen,

\section{2) Sociological Reasons for the Need for a Law on Domestic Workers}

The problem of domestic workers in Indonesia cannot be separated from the cultural system prevailing in society. The current paternalistic relationship puts forward the view that domestic workers are part of a family, so that the working relationship that occurs is a kinship relationship. One of the reasons for the absence of laws and regulations that specifically protect domestic workers is that domestic work services in Indonesia are not considered a formal employment relationship, but only as an informal employment relationship between domestic workers and employers. The domestic worker profession has its own characteristics, both in its work area which is in a private space (household), type of work, working time, and working relationship with the employer. In certain communities, the relationship between domestic workers and employers is more familial. In some cases, Domestic workers encountered generally still have a family relationship with the employer, so that the wages received are not always in the form of money, but in other forms such as school fees. In addition, in the Javanese tradition there is the concept of ngenger culture, where a family can invite relatives who are economically disadvantaged to live in their house. In this tradition, young boys and girls leave their villages to live with uncles, aunts or other wealthy relatives in the hope that the children will be educated and well cared for. In return, these children are expected to help with household chores. Conditions like this do make them feel comfortable to work and do it with joy, but on the other hand,

3) Juridical reasons for the need for a law on domestic workers

Juridical considerations concerning legal issues and the role of law in regulating the protection of domestic workers. This is related to the role of law in development, both as a regulator of behavior (social control), as well as an instrument for problem solving (dispute resolution). The law is very necessary, because the law or legislation can guarantee certainty and fairness in regulating the protection of domestic workers. Along with developments that occur in society, the presence of domestic workers is increasingly needed and the quantity is increasing in number. However, the protection of this profession is still not adequate. Until now there are still many problems faced by domestic workers, ranging from Wages that are not paid or paid but not properly; working hours outside the normal limits; to harassment or violence, whether physical, psychological, sexual, or neglecting the household. In formal juridical terms, there are no specific laws and regulations governing domestic workers. The working conditions of domestic workers are completely dependent on the employer. If the employer treats it well, then the domestic worker has and receives reasonable working conditions.

\section{c. Non-Governmental Organization (NGO) Version of the Domestic Worker Law}

1) Philosophical reasons for the need for a law on domestic workers

That work is a manifestation of personal existence and values in social life as the fulfillment of human rights protected by law based on Pancasila and the 1945 Constitution of the Republic of Indonesia. in accordance with human dignity. To prevent discrimination and violence against 
Domestic Workers, a system that guarantees and protects Domestic Workers is needed. Protection of Domestic Workers is aimed at ensuring the fulfillment of the basic rights of Domestic Workers and the welfare of Domestic Workers and their families. in order to guarantee protection and improve the quality of life, domestic workers have the right to education and training. The work of Domestic Workers is different from other workers and therefore requires separate legal protection.

\section{2) Sociological Reasons for the Need for a Law on Domestic Workers}

As a worker, regardless of gender and background of social class, economy, education, origin, race, ethnicity/nation, religion and belief, area of work, choice of profession and field, they should receive respect, protection of their human rights, their rights as workers, their rights as citizens, as the universal principles of human rights, the 1945 Constitution of the Republic, Law Number 7 of 1984 concerning the Ratification of the Convention on the Elimination of All Forms of Discrimination Against Women, Law Number 391999 concerning Human Rights.

However, respect, enforcement - such protection should be attached to Domestic Workers (PRT), does not occur in this group of workers. The Existence of Domestic Workers and the Socio-Economic Contribution of Domestic Workers to Various Aspects of Life The existence of domestic workers has benefited many households, but their work is not yet considered a profession that deserves respect. This is related to the patriarchal social construction that does not value domestic work (domestic sector). In patriarchal culture, domestic work is considered as the natural work of women as housewives. Because it is considered as something that is inherent in the nature of women as mothers, daughters, the work is not given an economic value. As a result, when the work is done by someone else, it is enough to be given a low wage. Especially in a feudal system, class bias, if it is seen that domestic workers come from poor families, then low wages are also considered enough to appreciate them.

\section{3) Juridical reasons for the need for a law on domestic workers}

As a worker, regardless of gender and background of social class, economy, education, origin, race, ethnicity/nation, religion and belief, area of work, choice of profession and field, they should receive respect, protection of their human rights, their rights as workers, their rights as citizens, as the universal principles of human rights, the 1945 Constitution of the Republic, Law Number 7 of 1984 concerning the Ratification of the Convention on the Elimination of All Forms of Discrimination Against Women, Law Number 391999 concerning Human Rights.

However, respect, enforcement of such protection should be attached to Domestic Workers (PRT), does not occur in this group of workers. Protection of domestic workers and work relations in the household sector with distinctive characteristics, this Law is a labor law that specifically regulates matters that have not been regulated in the existing labor legislation.

Therefore, the Law on the Protection of Domestic Workers regulates the following matters:

a) General provisions regarding the meaning and limitations of parties who are legal subjects and other parties who are related aspects;

b) Foundation, principle and purpose;

c) Classification of domestic workers according to working time, type of work category;

d) Employment relationship which includes work agreement, rights and obligations of the parties;

e) The lowest age limit for domestic workers to work;

f) Limitation of the role of PRT information service providers;

g) Domestic Workers Union as a representative organization for domestic workers;

h) Domestic Work Relations Cooperation Institution as an institution that is given the authority to bridge relations between parties, formulate policies;

i) Employment dispute resolution mechanisms with various options and stages of the method taken by the parties through deliberation for consensus, mediation, arbitration or 
domestic labor relations courts which are mandated to be held to accommodate the need for dispute resolution for which there is no mechanism;

j) Work termination;

k) Education and training to build work skills and quality of life of domestic workers;

1) Budget to meet the necessary costs for the implementation of this Law;

m) Joint supervision involves elements of the government, the community;

n) Criminal provisions, administrative sanctions and victim recovery;

o) Transitional provisions for the elimination of children who work as domestic workers;

p) Closing.

Thus, the Law on the Protection of Domestic Workers is one of the manifestations of what was mandated when the Republic of Indonesia was established which aims to protect the entire Indonesian nation and the entire homeland of Indonesia and to promote public welfare, educate the nation's life and participate in carrying out world order based on independence, peace. immortality and social justice.

\section{Conclusion}

Legal Position of Domestic Workers (PRT) in Work Law in Indonesia. Domestic workers are definitively recognized for their legal position as workers as referred to in Law Number 13 of 2003 concerning Manpower. According to Article 86 paragraph 1 of Law Number 13 of 2003 concerning manpower it is stated that: "Every worker/labor has the right to obtain protection for (a) occupational safety and health, (b) morals and decency; and (c) treatment in accordance with human dignity and values as well as religious values."

Settlement of Cases Experienced by Domestic Workers (PRT) In a family way to reach consensus and through a mediation process. The deliberation and consensus process is carried out between domestic workers and employers and/or domestic service providers as the simplest step to resolve disputes. Deliberations were taken for the first time without the involvement of local government officials. However, if necessary, local government officials can serve as witnesses in the deliberations. In making decisions through deliberation to reach consensus, time is limited so that it does not drag on and a sense of justice is fulfilled in an effort to provide legal certainty for the parties.

The Need for Special Arrangements for Home Workers, because the work is done within the household and is considered informal work, there are no regulations governing it, and as a result it often goes unnoticed. This is a category of work that is in dire need of legal and social protection, as its workers are vulnerable to harassment and exploitation during recruitment and placement, during work, and upon return to their place of origin. This paper summarizes the main problems faced by domestic workers, as well as the obstacles experienced in obtaining their rights

\section{References}

Dhevy Setya Wibawa \& Laurike Moelino, Research Report: Profile of Child Domestic Workers in Two Areas of South Jakarta: A Study to Increase Public Awareness. Jakarta: Atma Jaya Unika PKPM, 2002.

Dwi Astuti, et al. Footprints of a Thousand Hands, Yogyakarta: 1999.

Edriana Noerdin, Situation of Domestic Workers (PRT) in Indonesia, Tjoet Njak Dien GROUPS. 2004.

Johnny Ibrahim, Normative Law Research Theory and Methodology, Malang: UMM Press, 2007.

Indonesian Women's Legal Aid Institute (LBH APIK), Position Paper on Proposed Revision of DKI Jakarta Regional Regulation No. 6 of 1993 concerning Pramuwisma [Position Paper and Recommendations 
for the Revision of Jakarta City Local Ordinance No 6 of 1993 on Domestic Workers] LBH APIK Jakarta, 2002.

Komnas Perempuan \& Solidaritas Perempuan/CARAM, "Indonesian Domestic Workers Migrant Workers (TKW-PRT): Vulnerabilities and New Initiatives for the Protection of the Human Rights of TKW-PRT" in Indonesia's Report to the United Nations Special Rapporteur on the Rights of Migrants, Jakarta 2003.

Khudzaifah Dimyati \& Kelik Wardiono, Legal Research Methods, Surakarta: Muhammadiyah University of Surakarta, 2004.

Then Husni, Introduction to Indonesian Manpower Law, Jakarta: Raja Grafindo Persada, 2000.

Muryanti, “Efforts to Protect Domestic Workers", Jurnal Perempuan, Vol 39, January 2005, p. 15. See also "Activists Call for Ruling to Protect Domestic Workers", The Jakarta Post, 10 March 2005.

Purbacaraka and Soerjono Soekanto, Joints of Law and Legal Administration, Bandung, Alumni, 1986.

Syarief Darmoyo \& Rianto Adi, Child Trafficking for Domestic Workers: Case Jakarta, Jakarta: PKPM Unika Atma Jaya 2000.

Soedikno Mertokusumo, Knowing the Law (An Introduction), Yogyakarta: Liberty, 1988.

LBH Apik Team, Position Paper, Proposed Revision of DKI Jakarta Regional Regulation No. 6 of 1993 concerning Pramuwisma, Jakarta: 2002

WJS. Purwodarminto, General Indonesian Dictionary, Jakarta: Balai Pustaka, 1959.

Emiarti Fuad, staff of the Deputy for Women's Protection, Ministry of State for Women's Empowerment.

Human Rights Watch, Always On Call: Abuse and Exploitation of Child Domestic Workers in Indonesia, Vol 17.7(C), 2005.

Discussion with Dr Irma Alamsyah Djaya Putra, Deputy Head of the Women's Protection Section at the Women's Empowerment Department, 3 October 2005.

In 2001, LBH APIK handled 15 cases involving serious abuse of domestic workers, 13 cases involving the murder of domestic workers, and 3 cases involving the rape of domestic workers. Indonesian Women's Legal Aid Institute (LBH APIK), Position Paper on Proposed Revision of the DKI Jakarta Regional Regulation No. 6 of 1993 concerning Pramuwisma [Position Paper and Recommendations for the Revision of Jakarta City Local Ordinance No 6 of 1993 on Domestic Workers] LBH APIK Jakarta, 2002

Human Rights Watch, Always On Call: Abuse and Exploitation of Child Domestic Workers in Indonesia, Vol 17.7(C), 2005.

For example in some areas in West Nusa Tenggara and North Sumatra, with different terms.

This can be seen, for example, in the case of a domestic worker named Kamrah who is currently being handled by the Mataram City Police, West Nusa Tenggara. Kamrah ran away from his employer/employer's house because he was held captive and had not been paid his wages for 10 months. It is indicated that this is because the employer thinks that Kamrah is the result of remuneration from Kamrah's distant relatives who have been successfully sent as TKI.

Decision of the Central Labor Dispute Settlement Committee No. 70/59/111/02/C dated December 19, 1959.

“Minim, Legal Protection for Domestic Workers", Suara Karya Online, 17 January 2004, <http://www. Suarakarya-online.com/news.html?id=78569>. This point was emphasized in a discussion with Dr 
Irma Alamsyah Djaya Putra, Deputy Head of the Women's Protection Section at the Women's Empowerment Department, 3 October 2005.

http://hotibin-ebink.blogspot.com/2009/07/nasib-pekerja-rumah-Rumah-prt.html, accessed on August 1, 2013.

www.lbh-apik.or.id/prt\%20-\%20ruu\%20versi\%20jala.html, accessed 16 October 2013.

People's Thoughts, Domestic Workers' Salaries Must Be Equal to the UMR, Thursday, April 162009. Executive Coordinator of the SAHDAR NGO, TR. Arif Faisal, SH.

Okky Asokawati Member of Commission IX DPR RI, "Managing the Protection of Domestic Workers", Republika March 5, 2012 